\title{
THE UNCERTAIN REFORM TO THE CHILEAN PENSION SYSTEM
}

\author{
A REFORMA INCERTA DO SISTEMA PREVIDENCIÁRIO DO CHILE
}

Ivan Obando Camino*

\begin{abstract}
This paper describes the attempts to introduce some solidary features into the private pension system and the reform strategy followed thereof by left-wing governments in Chile since 2008. The negative impact on retirees of a private pension system driven by financial markets and profit-oriented actors has led to a continuing questioning of this system by experts and the population. The strong veto powers that major industry actors hold in the policy process determined that those governments adopted an institutional reform strategy based on layering. This paper surmises that this strategy may a have an impact on the pension system in the long-term by steering it gradually towards a public pension system.
\end{abstract}

Keywords: Social security. Pension system. Solidarity system.
Resumo: Este artigo descreve as tentativas de introduzir algumas características solidárias no sistema de previdência privada e a estratégia de reforma seguida por governos de esquerda no Chile desde 2008. O impacto negativo sobre aposentados de um sistema de pensão privado que foi impulsionado por mercados financeiros e por atores lucrativos levou a um contínuo questionamento desse modelo por especialistas e pela sociedade. $O$ forte poder de veto que os principais atores da indústria mantêm no processo político determinaram que esses governos adotassem uma estratégia de reforma institucional estratificada. Este artigo supõe que esta estratégia pode ter um impacto no sistema de pensões a longo prazo orientando-a gradualmente para um sistema público de pensões.

Palavras-chave: Segurança social. Sistema de aposentadorias. Regime de solidariedade.

\footnotetext{
"Master of Arts and Ph.D in Political Science from The State University of New York in Albany; Professor of Public Rights and Politic Science in Universidad de Talca, Chile; Avenida Lircay, Talca, VII Región, Chile; iobandoc@utalca.cl
} 


\section{Introduction}

On July $27^{\text {th }}, 2016$, Chileans peacefully protested in major cities against the meager pensions paid by the pension industry, better known as the Administrators of Pension Funds (AFPs from now on), created by the military dictatorship in 1981, which they considered a breach to of their fundamental right to social security provided for in international covenants and the political constitution.

This protest was unusual because complete families-and their relatives-marched throughout the country convened by a social movement called "No More AFPs", after it was found out that the former wife of the House Speaker, Representative Andrade, received a millionaire pension under the public distribution system of the National Prison Agency personnel; in other words, paid by the taxpayers.

The President of the Republic, Mrs. Michelle Bachelet, announced a major pension reform through national television three weeks later, whose major guidelines coincide with the recommendations made by the Presidential Advisory Committee on the Pension System, better known as the "Bravo Committee", appointed two years ago by her.

This committee finished its deliberations and recommendations in late 2015, which intended to fix the existing pension system, but there was no room for policy-making at that time for the current administration.

Nowadays there is no doubt that the national protest held in July provided a window of opportunity for the administration to bring the subject of pension reform at the forefront of the national debate (coincidentally at election times), from which it has not receded so far. Nevertheless, the current administration already stated that it would not introduce legislation into Congress until late 2016 or early 2017. Moreover, opponents to the pension reform closed ranks thereafter to prevent the introduction of new redistributive or solidary amendments to the pension system, carrying out even massive e-mail campaigns targeted at AFPs clients, which foreshadows a deep confrontation on the reform subject in Congress.

The political conflict described here above illustrates on the tensions that arise from challenging a thirty-five years institutional trajectory on social security driven by financial markets and profit-oriented actors, notwithstanding the normative deficits of legal regulations from an international law perspective and the negative forecasts about the benefits provided by that pension system (Obando, 2016, pp. 614-630).

This is hardly surprising because persistence, stability, and self-reproduction are distinctive features of an institutional order that has been in place for quite a while, which tends to project itself over time counting on its supporters. In a sense, O'Donnell (1997) tapped into this characteristic of institutions, as follows: ". . it is expected that institutionalized interactions will remain in the future with the group of agents (or with a group in slow and foreseeable change)" (p. 222).

Nevertheless, institutions change becoming thus unrecognizable in the long-term. Indeed, oftentimes long-established institutions change through piecemeal incremental reforms im- 
plemented over a long stretch of time, which cumulative effects transform the overall purpose of that institution through layering, even though that institution may look unchanged on the surface (Pierson, 2004, pp. 153, 156). The latter springs out of the difficulty that institutional reformers face in contexts characterized by the presence of actors with strong veto powers who provide support to the existing institution (Mahoney \& Thelen, 2010, pp. 18-22). In these circumstances, makes much more sense using these incremental strategies of institutional change, instead of using a type of "rock the boat" strategy that will activate strong opposition of those actors and doom a reform agenda from the very beginning.

Somehow, reforms introduced to the pension system eight years ago and their impact in the overall functioning thereof strongly suggest that layering has been place since then, so it is fair to interpret the current political conflict as a new chapter in the administration attempts to straighten the pension system towards a more distributional approach along these lines, although under an increasing political pressure that besieges not only the government, but also the pension industry for the first time.

In a sense, it is too early to assert that the current administration achieved a major breakthrough in the policy process regarding the pension system. It is much more advisable to speak of a stalemate for the time being, although it is not far-fetched to suggest that incremental reform may beagain - the result of all of this, like it happened in the last reform to the pension system passed in 2008.

The current conflict on pension reform in Chile has major implications for public policy from a comparative viewpoint, because it highlights the constraints that policy reformers face to introduce institutional change under contexts of several veto players, all of which have been around for quite a while, which brings uncertainty to bear on the end result of this policy conflict.

This chapter provides an overview of the major issues involved in this policy conflict, for which purpose it adopts a descriptive approach to deal with major aspects of the Chilean pension system (the pension system from then on). Likewise, it summarizes-from official sources-the recommendations to address its shortcomings proposed in late 2015 by the Bravo Committee, and the reform proposals announced recently by President Bachelet, which have raised major objections by opponents from several quarters.

\section{The legal architecture of the pension system ${ }^{1}$}

The Chilean constitution recognizes to every person the constitutional right to social security in Article 19 n. 19, but it does not say anywhere what is the content of this right, lest speak of protection under a writ of mandamus. Indeed, the constitutional clause only says that there will be basic uniform benefits for everyone and a law will regulate the conditions to exercise this right; in other words, the constitution provides for a programmatic constitutional right to social security under the scheme of a hands-off, non-activist subsidiary role for the government (Obando, 2016, pp. 622-623).

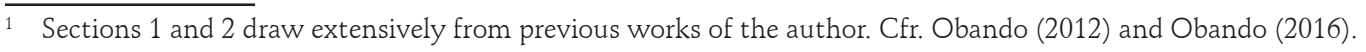


In these circumstances, a private, non-solidary management of risks and social contingencies characterizes the current Chilean pension system enacted by the military dictatorship in 1981, which is mandatory for all people who entered the labor force from 1981 on, as well as for those who transfer from the former, public distribution system thereafter. On the contrary, the military, the police, and the prison personnel, remained in their own public, distribution system funded mostly by taxpayers.

According to the legal architecture of the pension system, private corporations administer and invest workers' pension funds in different type of assets, including foreign assets, under strict government regulations which -in the worst case scenario- do not rule out possible financial losses at times of economic turbulence, e gr. the sub-prime crisis. In this respect, the AFPs sole legal objective is to administer and invest these pension funds, which authorizes them to charge administration fees to their clients - the workers - , regardless of any profit or loss incurred into during the month. Workers do not participate in the administration of AFPs under this legal framework, although they participate in a Committee of Users of the Pension System that advises the Vice-Secretary of Social Welfare about the users' evaluations, besides proposing promotional and educational strategies about it.

These pension funds come from monthly contributions made by all workers, who deposit no less than $10 \%$ of their monthly taxable income in individual accounts in the AFP of their choice. Likewise, workers who perform heavy work must contribute another $2 \%$ of their monthly income to their individual accounts. In practical terms, employers deduct these contributions from their workers' monthly salary, do the paper work, and deposit them in AFPs; otherwise, AFPs can collect these contributions from employers in courts, which may impose them harsh fines, besides criminal charges of fraud. Unfortunately, these instrumentalities have not deterred many employers from taking away their workers' contributions, nor made AFPs more responsible in collecting these debts.

The monthly taxable income for retirement purposes cannot exceed US\$2,900 app. by law, whatever is the worker's real income. The latter implies that most workers save the minimum $10 \%$, which will not allow them to make ends meet during their retirement, unless they save more money through other financial instruments provided by the pension system, i.e. second individual account or voluntary pension contributions (APV). However, these are options available only to a small fraction of the work force, e. gr. professionals, CEOs, administrative leaders, etc.

The pension system also allowed voluntary contributions by self-employed workers under the same rules, after taking into account the historical experience of these workers under the previous distribution system. Nevertheless, that experience became a better predictor of their current behavior, given their dismal level of savings. In this regard, the reform passed in 2008 made mandatory that these workers contribute gradually to their pension fund; otherwise, the government could deposit their annual tax returns in an AFP. In any case, self-employed workers' contributions to their pension funds did not fulfill all the reform expectations, because most of them refused to contribute to their pension fund during the transitional period from 2008 to 2016, while many others under-declared their annual income before the Internal Revenue Service. 
Nevertheless, unforeseen conditions of the labor market and informal labor relations plagued the efficacy of the pension system to provide universal coverage and to provide sufficient benefits to everyone, depriving the pension system of equality, sufficiency, and universality, as required by the traditional principles of social security enshrined in international instruments passed by United Nations and the International Labor Organization.

On the other hand, workers choose the specific pension fund wherein they wish to deposit their contributions, for which purpose a reform passed in 2002 created five pension funds - the so called "multifunds" - that differ in their profitability and financial risk, i.e. A, B, C, D, and E. Thus, fund $\mathrm{A}$ is the most profitable and most exposed to financial risks in the short-term, whereas fund $\mathrm{E}$ is the least profitable and least exposed to financial risks in the long-term. If a worker does not choose a specific fund for any reason, the AFP will deposit his or her contributions into a "default fund"- - usually Fund C-until the worker voluntarily transfers them to another fund.

Although AFPs advice their clients on the most recommended fund according to their risk tolerance and the law also forbids workers approaching their retirement age to deposit their funds in the riskiest fund, financial decisions made during a complete work life require a level of financial education that is beyond the scope of most people, including the highest educated workers.

AFPs invest the workers' funds in different financial instruments, which may consist of equities or fixed income securities portfolios, both national and international, in accordance with the directions provided by their clients. In any case, a governmental committee determines these instruments beforehand to reduce the risk of financial losses. AFPs must guarantee a minimal, annual profitability of investments before their clients, the so-called minimal legal profitability, but the latter is determined based on computations that factor in a three-year period; otherwise, AFPs must pay to their clients the differential between the real profitability and the minimal legal profitability by using their legal reserves (the so-called encaje). Besides, AFPs must also compensate the damages caused to their clients' individual accounts if they fail to follow their directions or to fulfill their legal obligations.

Employers do not contribute to their workers' pension funds, but a reform passed in 2008 provided for their funding of a very small part of the monthly fee charged by AFPs, as well as the disability and survival insurance. Likewise, employers contribute to the pension fund of workers who perform heavy work, which amounts from $1 \%$ to $2 \%$ of the workers' monthly taxable income, depending on the wear caused by the type of work. It goes without saying that this employer contribution hardly amounts for something that resembles solidarity in the overall design of the pension system.

The pension funds deposited in AFPs belong to their clients, that is, the workers, who cannot withdraw them until retirement or in case of disability, but always under the options provided by law. The government guarantees to some extent-under some circumstances-the pension funds deposited in AFPs in case of bankruptcy or insolvency (Lanata, 2015, pp. 105-106).

Regarding benefits, the law provides for retirement at 60 years old for women and 65 years old for men, but their different official mortality rates reach well beyond their official life ex- 
pectancy, which creates serious problems for would be retirees who have not saved enough during their work life, especially women.

The pension system provides benefits for retirement and disability (total or partial) under different legal hypothesis. Thus, workers may use their individual account balance to fund any of the following pension options: immediate annuity paid by an insurance company; immediate annuity paid by an insurance company and scheduled withdrawal of funds accumulated in an AFP; temporary rent with differed annuity paid by an insurance company; and scheduled withdrawal of the funds accumulated in the AFP. The government guarantees to some extent these immediate annuities, in case of bankruptcy of the insurance company (Lanata, 2015, pp. 132-133, 236-238).

In this regard, there is consensus that the pension system is expensive because the real profitability accrued to pension funds offsets neither financial losses nor low contributions made throughout a work life. Thus, the Chilean pension system offers to its beneficiaries some uncertain benefits while demanding certainty in their financial contributions (Gumucio, 2009, p. 170) or, in other words, it rewards them with uncertain financial options that make precarious the Chileans' right to social security (Fernández, 2013, p. 363).

Indeed, there is not a reasonable equivalence among income, contributions, and the pension system benefits, as required by the United Nations General Observation n. 19, of 2008 (Arellano, 2012, pp. 256-277). The latter is hardly surprising because it definitely is not a social insurance as required by Article 9 of the International Covenant of Cultural, Social, and Economic Rights, making thus difficult for the government to ratify the International Labor Organization Covenant n. 102, of 1952 (Gumucio, 2009, p. 170).

Thus, the Chilean pension system departs from most of the principles of international human rights regarding social security, because it is just a means to siphon off resources from the work force to strengthen the general economy, for which purpose the isolation of the government from social pressures was a key ingredient in 1981.

\section{Recent amendments to the pension system ${ }^{2}$}

The deleterious effects of the pension system on retirees who transferred from the public distribution system in 1981, as well as the scarce savings of most workers who joined the work force after 1981, persuaded President Bachelet to appoint an advisory committee on pensions in 2006. Economist Mario Marcel chaired this committee, also known as the "Marcel Committee", whose recommendations determined a number of reforms passed in 2008.

First and foremost, this reform created a Solidary System of Retirement and Disability, better known as the "solidary pillar", responding thus to the fact that most workers lack enough income to fund their retirement or disability pensions under the pension system.

$\overline{2}$ Cfr. Obando (2012) and Obando (2016). 
In this respect, the Marcel Committee poignantly pointed out that most of the population will lack any pension in the future or this pension will be extremely small, given economic, technological, and labor developments.

Originally, people in these circumstances applied either to a minimal pension or to an assistance pension. The former benefitted retirees whose pension was very low, regardless of their economic conditions, but required that the retiree had contributed for no less than 240 months to the pension system. The amount of the benefit depended on the age of the beneficiary, so it ranged from US\$ 176 through US\$ 205 monthly as of 2013. The latter constituted a government transfer that pursued to relieve poverty of elderly and disabled people who had very low income and lacked any contributory pension, all of which could to apply to this government benefit which did not exceed of US\$ 87 monthly in case of retirement and US\$ 81 in case of disability as of 2013. However, the awarding of this benefit depended on the existing financial resources as provided by the annual budget law. Therefore, is fair to conclude that the most vulnerable people faced complete uncertainty regarding the awarding of any of these pensions, because the minimal pension required 240 monthly contributions at least, while the assistance pension depended on existing government resources (Larrañaga, Huepe, \& Rodríguez, 2015, pp. 161-162).

The government response to this failure on universality consisted of creating a solidary, non-contributive means-tested subsystem to include these people in the social security net, which functions in the absence or insufficiency of contributions. The newly created Institute of Social Welfare has legal responsibility to administer this subsystem, including the corresponding benefits. The Superintendence of Pensions, in turn, oversights this solidary subsystem.

This subsystem provides the following benefits:

a) Basic solidary pension of retirement: it is a retirement pension payable to any person who reaches 65 years old, lacks any type of pension under the existing social security laws, integrates the poorest $60 \%$ of the national population, resides in the national territory for at least 20 years, whether or not continuous, since reaching 20 years old, and in any case for no less than 4 years in the 5 years previous to their application. In the case of indigents, the computation of this term begins with their birth date (US\$ 142 app.)

Importantly enough, there is an age requirement to request this pension, that is, 65 years old, regardless of the gender. Government opposed congressional attempts to reduce this age requirement for women based on the idea that its awarding should follow the same logic of the preexisting pensions. Nonetheless, the government offset the latter through a new government contribution that goes into the individual accounts of female workers who adopted or gave birth to a children alive (Larrañaga, Huepe, \& Rodríguez, 2015, p. 168).

b) Basic solidary pension of disability: it is a disability pension payable to those who are declared disabled by official boards, lack any type of pension under the existing social security laws, are from 18 through 65 year old, reside in the national territory for no less than 5 years in the 6 years previous to their application, and are part of a family group that integrates the poorest $60 \%$ of the national population (US\$ 142 app.) 
c) Welfare solidary contribution of retirement: it is a contribution that increases existing retirement pensions awarded under the pension system (US\$ 461 app.), when the original pension does not exceed a legal cap.

d) Welfare solidary contribution of disability: it is a contribution that increases existing disability pensions awarded under the pension system, when the original pension does not exceed a legal cap.

Although the government intended to implement this subsystem gradually over an eightyear time-period, Congress decided to shorten this timetable to have an impact as soon as possible, as there already was an ample consensus on the objectives and means of this program. Congress thus passed legislation to implement this program within four years, so the political elite endorsed this program from the very beginning. This support made possible that the government paid these new entitlements to $93.4 \%$ of the eligible population by 2011, which turned this program into a very successful policy initiative of the first Bachelet Administration (Larrañaga, Huepe, \& Rodríguez, 2015, pp. 166-168, 174-176). Thus, government expenditures for the solidary pillar reached up to $0.7 \%$ of the 2013 GDP, which amounts to almost one-half of the total government monetary transfers, $4.9 \%$ of the total social expenses in that fiscal year, and $23.6 \%$ of all contributory pensions paid at that time (Larrañaga, Huepe, \& Rodríguez, 2015, pp. 171-172).

No doubt, the introduction of this solidary subsystem addressed the failure on universality of the pension system for the very first time, just as budgetary estimations point out that it will benefit two million people app. with a total estimated expenditure of $1.4 \%$ GDP by 2025 (Larrañaga, Huepe, \& Rodríguez, 2015, p. 172): ${ }^{3}$ however, the small amount of money paid by these pensions (especially, the solidary pensions) still cast doubts on their sufficiency to provide for a dignified life. However, it is clear today that the pension system consists of one pillar made up of both a contributive and a non-contributive component (Arellano, 2012, p. 212), but the non-contributive component somehow overlies the contributive one and has much more importance for most of the Chilean population.

The 2008 reform also addressed other problems generated by the pension system. Thus, it introduced new financial instruments to induce retirement savings, some of which are available during collective bargaining among unions and employers. It also dealt with self-employed workers by making mandatory their contributions, which implied that they gained access to the solidary subsystem too. Likewise, it addressed some of the gender welfare gaps, such as the welfare problems of homemakers, for which purpose it included retirement savings of husbands among the assets that a judge may distribute during divorce proceedings. By the same token, it extended the length of the female disability and survival insurance up to 65 years old, as a way to induce female workers to save more money by retiring later, and created a government contribution that goes directly into the individual accounts of female workers who adopted or gave birth to a children alive, as said above.

3 The Pension Reserve Fund, created in 2006, provides additional funding for the increasing expenditures of this pillar until 2021 app. (Larrañaga, Huepe, \& Rodríguez, 2015, pp. 172-173). 
Finally, it included husbands among the recipients of survival pensions drawn from their deceased wives' individual accounts.

\section{The analysis of the pension system by the Bravo Committee ${ }^{4}$}

President Bachelet appointed a Presidential Advisory Committee on the Pension System on April 2014, fulfilling thus one of the promises made during her presidential campaign. Economist David Bravo chaired this committee, also known as the "Bravo Committee". The committee's goal was to analyze the functioning of the pension system at that time and to draft policy proposals that addressed the deficiencies detected therein.

The Bravo Committee pointed out that the pension system comprises both self-funded and subsidized benefits for retirement, disability, and survival, but mandatory contributions for self-funded benefits remained low after 2008, because on the one hand workers contribute only $10 \%$ of their monthly taxable income and on the other hand there is almost no contribution from employers. In addition, the accumulated transitions costs from the previous to the current system amount today to $136 \%$ of the 1981 GDP, but the total transitions costs will reach up to $2.7 \%$ GDP by 2025 , though they will totally exhaust by 2050 . On this vein, government dealt with these transition costs mostly through fiscal austerity, which made possible the development of a secondary market. Finally, government expenditures for the solidary pillar reached up to $0.7 \%$ of the 2013 GDP, ${ }^{5}$ which implies the existence an exogenous solidarity that comes from the government, because there is not solidarity among AFPs clients or generations.

Regarding the functioning of the pension system, the committee maintained that it evinces an increasing aging of the population since the late 1960s, which casts doubts about the long-term sustainability of the pension system already by 2025 , because the ratio between active and passive people will decrease from 5:1 in 2010 through 1.8:1 by 2050. Likewise, it is apparent that life expectancy will increase for all the population over time, but less for the poorest people in a context in which there is enough government support for elders, so relatives-especially womenwill be hard-pressed to take care of them. Similarly, it pointed out that most retirees have some type of income that amounts to $67 \%-70 \%$ of the income of the active population, but it depends on the educational achievements of everyone.

On a more disturbing fact, it found that people spend $41.2 \%$ of their work life (18-60 years old) as salaried, although there is a gender gap regarding this matter (men 53.3\%; women 29.1\%); actually, women spend almost half of their labor life without income. The official mortality rates passed by the government worsen the situation of women, because they assert that female life ex-

\footnotetext{
4 Sections 3. and 4. draw extensively from the final report released by the Presidential Advisory Committee on the Pension System in late 2015, summarizing the major findings and policy recommendations thereof (Presidential Advisory Committee on the Pension System, 2015, pp. 61-149).

5 In any case, solidary pensions reached to $61.2 \%$ of the total benefits, whereas solidary contributions reached to $38.8 \%$ of the 2013 expenditures, although the rise in solidary contributions was faster after 2011 (Larrañaga, Huepe, \& Rodríguez, 2015, p. 169).
} 
pectancy is 29.46 years after 60 years old, in circumstances that they assert that male life expectancy is 20.07 years after 65 years old. Moreover, the functioning of the labor market makes matters even worse, because it tends to discard people after 65 years old, even though the average retirement age is 69.1 years for men and 64.8 years for women. Furthermore, welfare evasion by employers, the problem of self-employed workers who opt out of the pension system, and the existence of non-taxable salary items for both retirement and income tax purposes, have a significant impact on the level of pension savings.

Interestingly enough, it confirmed that there is low competition in the pension industry and workers are not sensitive enough to the fees charged by AFPs (1.14\% average monthly fee as of 2015). The pension industry has no incentive to push for fees reduction all across the board; moreover, there are fees that are non-visible for AFPs clients, because AFPs draw them from their client's total pension funds, i.e. exchange fees.

It also detected that people do not know enough about the pension system and hold in low esteem the industry according to public opinion polls, but they know more about the solidary pillar. Likewise, it found that transfers among the five pension funds by AFPs clients has been on the rise, in circumstances that individual investment strategies based on these frequent transfers do not spell for increasing profitability for AFPs clients in the long-term.

Regarding specific benefits, it maintained that scheduled withdrawals keep ownership of pension funds in the hands of retirees, though they expose them to decreasing payments over time. Immediate annuities, in turn, keep the purchasing power of their pension, but they imply a transfer of their ownership to an insurance company, besides exposing them to financial turbulences at that time. In addition, there are differences between real, annual net profitability and individual accounts profitability, because the former reached an average of 8.6\% from 1981 through 2013 annually, whereas the latter-without fees-reached 5.4\% from 1981 through 2009 annually.

On this vein, the contributions to pension funds did not exceed of $79 \%$ of the work force by 2013 , but almost half of those workers had a median density of contributions that amounted to $40 \%$ of their work life, whereas one-quarter of them had a density equal or less than $11 \%$ (women reached an average of $33.3 \%$ ). The latter has an immediate impact on the median worth of self-funded pensions, which reached up to US\$ 57 and US\$ 125 app. from 2007 through 2014, depending on whether or not it excluded the welfare solidary contribution of retirement. To make matter worse, the median replacement rate was 34\% for all retirees, which reached to $46 \%$ after including the welfare solidary contribution of retirement; however, the projected replacement rate half of those who will retire from 2025 through 2035 will be about 15\% only. ${ }^{6}$ Last but not least, the committee warned about a decrease of replacement rates in the long-term, as follows: "Although the significance of the Welfare Solidary Contribution will be greater for future generations of retirees, it is expected that the total replacement rate, including that contribution, will be smaller than today's

\footnotetext{
6 The median replacement rate for workers who contributed less than 190 months would be $3.8 \%$, whereas the median replacement rate for those who contribute more than 400 months would be 38.9\% (Presidential Advisory Committee on the Pension System, 2015, p. 91).
} 
generations' replacement rate, independently of the contribution income section" (Presidential Advisory Committee on the Pension System, 2015, p. 91). ${ }^{7}$

4. The policy recommendations of the Bravo Committee ${ }^{8}$

The Bravo Committee entertained three global proposals to address the deficiencies of the pension system. These proposals were named as Proposal A, B, and C. Committee members voted on these proposals in a plenary session held in late July, 2015, wherein its twenty-four members carefully weighed in their pros and cons. The results were, as follows: Proposal A, 12 votes; Proposal B, 11 votes; Proposal C, 1 vote.

Proposal A built upon the reforms introduced to the pension system in 2008. It strengthened both the non-contributive and the contributive components thereof, addressed issues of gender equality, and introduced new incentives to stimulate long-term savings, investment, and economic growth to make the pension system financially sustainable.

This proposal sprung out of the idea that using pension funds currently accrued in AFPs to solve today's pension problems implied depleting savings of future generations at a time of a declining natality rate and a shortage of the work force. The latter required a response that increases productivity through greater investments on social and physical capital, for which purpose it advised to increase government expenditure on the solidary pillar and to create a new $4 \%$ employer contribution to fund both workers' pension funds in AFPs and a new solidary fund.

Proposal B's supporters opposed this proposal because it kept the existing pension system without expanding its coverage and benefits. In addition, it did not bring about greater legitimacy to the pension system, it kept the uncertainty of the benefits and gender welfare gaps, it did not establish incentives to augment the density of contributions, and it did not reduce administrative costs. Proposal C's only supporter opposed this proposal based on the fact that it kept the existing pension system at the expense of greater government subsidies, contribution rates, and retirement age.

Proposal B, in turn, pursued a dual objective: on the one hand, to increase the legitimacy of the pension system, and on the other hand to respond to social security principles, for which purpose it created a social insurance based on solidarity among all people affiliated therein and among generations.

In order to do so, this proposal transformed the solidary pillar into a full-fledged social insurance that became the backbone of a new pension system funded by workers, employers, and the government. The organization of this new social insurance consisted of national citizen accounts of social security that expanded the coverage and sufficiency of today's solidary pensions, while keeping workers' contributions to individual capitalization accounts for monthly taxable incomes higher than US\$530.- app.

\footnotetext{
7 A comparison among the pensions paid by the pension system, the minimum wage, and the poverty line, from 2007 through 2014 , showed that $79 \%$ of those pensions were smaller than the minimum wage, whereas $44 \%$ of them were below the poverty line (Presidential Advisory Committee on the Pension System, 2015, p. 93).

8 Cfr. Presidential Advisory Committee on the Pension System (2015, pp. 61-149).
} 
In any case, all workers would be required to contribute $10 \%$ of their monthly taxable income to this new social insurance with a legal salary cap of US\$ 530.- app., whereas employers and the government would contribute another $10 \%$ to this solidary pension fund.

In so doing, it transformed the pension system insofar as the workers' contribution would go now to a general social insurance fund, turning thus contributions to AFPs in voluntary savings mechanisms available only to the well-to-do workers. The latter implied, of course, to depress financial investments in the secondary market and foreign asset by AFPs.

Regarding the benefits, it expected to induce a rise in today's pensions, to ease up the inclusion of self-employed workers into the social insurance, to relieve existing gender welfare gaps, and to introduce solidarity both into generations and among generations.

Proposal A's supporters opposed this proposal on the grounds that it made more difficult to fund future pensions, because it reduced savings and investments, it was a deficit-ridden proposal as the work force declines swiftly, it involved higher administrative costs, and it lack clarity regarding its redistributive effects. Proposal C's only supporter opposed this proposal because it did not solve the issues that currently plagued the pension system.

Finally, Proposal C took aim at responding concerns about the fairness of the pension system. It proposed to substitute a public distribution system for the current pension system by transferring AFPs clients, contributions, and savings to the new system.

In so doing, there would be an immediate $100 \%$ rise for the lowest retirement self-funded pensions; actually, contribution rates should not change until 2035 , while going up to $25 \%$ thereafter, so today's AFPs clients would have access to better, certain, non-discriminatory, life pensions. ${ }^{9}$

Committee members overwhelmingly opposed this proposal on the grounds of its longterm financial sustainability, because it did not offset patrimonial losses incurred into by AFPs clients, it implied a swift increase of taxes and contributions once the reserve fund depleted, and it reduced savings and investment at a time of declining natality rates, among other reasons.

Given that most members of the Bravo Committee supported Proposal A, the committee developed a set of fifty-eight policy recommendations to flesh in the objectives of that proposal. Interestingly enough, committee members clarified that the contributive component of this proposal was compatible with other pension savings schemes that exist in the Western world, but they did not spell out how to engineer this type of scheme (Presidential Advisory Committee on the Pension System, 2015, p. 102).

In a nutshell, the main committee recommendations were, as follows:

a) Fortifying the solidary pillar: this proposal fused all solidary benefits into a universal, means-tested solidary pension available for $80 \%$ of the population, so there would be a $20 \%$ rise for those who do not have access to any type of pension under the existing social security laws. Likewise, it provided financial incentives to postpone retirement, for which purpose it increased female

\footnotetext{
9 Pension benefits increased from $75 \%$ to $100 \%$, effective retirement age decreased to the retirement age required by law (65/60 years), and the cut-off of existing government subsidies make up for annual savings of up to 1.8 of the 2015 GDP (Presidential Advisory Committee on the Pension System, 2015, pp. 106-107).
} 
retirement age up to 65 years old, although and independent committee had to revise the minimum retirement age later to make the new system self-sustainable, especially considering OECD standards.

Funding for the solidary pillar would come from general taxes and a new employer contribution. Regarding the former, there will be an influx of new funds amounting $0.2 \%$ GDP from current and future taxes. Regarding the latter, employers will contribute $2 \%$ of their workers' monthly taxable income to this pillar, though there will be a review of the legal salary cap to include salary items that are not currently taxable for retirement purposes.

To implement these changes, gradualness was the name of the game: there will be a fiveyear time-period to carry out these measures.

b) Changing the contributive component of the pension system: monthly contributions to pension funds will remain in place along the existing requirements, but there will be a review of the monthly taxable income to include non-taxable salary items and to index that income to future salary increases. Likewise, employers will contribute $2 \%$ of their workers' monthly taxable income to the latter's pension funds in AFPs.

c) Introducing changes into the pension industry: the government will induce greater competition in the pension industry through creating a self-funded, government-owned independent AFP, which will compete with private AFPs. There will also be periodical public tenders of new contributors - new entrants to the labor market - to push down the monthly fees charged by AFPs, but this time it will include current contributors also to make more attractive competition among industry members. In any case, AFPs contributors will participate in the mechanisms that determine the cheapest AFP that receives these contributors through public tender.

To reduce exposure to financial losses by AFPs contributors, the system will re-assign contributors to a "default" pension fund over time in accordance to their age group, but there will be a reduction of the existing multifunds from five to three funds, one of which will include an option for passive administration. In addition, to cut-off administrative costs and entrance barriers to the pension industry, it proposed to reduce the legal reserves that each AFP must keep as a reserve fund. Finally, immediate annuities will be mandatory for all contributors, based on unisex, official mortality tables, so there will be an abrogation of scheduled withdrawals as a pension option for future retirees.

a) Addressing gender welfare gaps: to offset gender disparities that have a negative impact on pension savings, married couples and civil unions will share reciprocally their pension contributions during their life together at a rate of 50\% annually. On the other hand, considering that many people provide family care to their relatives, i.e. minors and elderly, the government will deposit a new bonus care in their AFPs individual accounts and introduce legislation into Congress to regulate comprehensively this type of family care.

b) Other proposals: to increase the density of contributions to pension funds, the government will implement better auditing programs to look after the observance of the social security laws and remove administrative bottlenecks that disincentive workers to contribute to their pen- 
sion funds. Furthermore, there will be a promotion of welfare and financial education for the whole population, especially workers.

5. Presidential proposals to reform the pension system

President Bachelet addressed the country on the night of August 8th 2016 through national television, wherein she announced the introduction of legislation into Congress to effect major amendments to the pension system.

The guidelines of the reform unveiled that night suggested that President Bachelet stuck closely to some of the recommendations put forward by the Bravo Committee, even though it is too early to determine the exact extent of the future reform package.

President Bachelet's initial remarks were straightforward, as follows: "Everyone needs a pension to have a dignified and quality life after years of labor. It is a right of everyone and needs to be a responsibility shared by all of us" (La Tercera Digital, 2016), so she spelled out five paramount policy measures that will inspire this new reform, as follows:

a) Fortifying the solidary features of the pension system, so it will become a tripartite system with participation of workers, employers, and the government. In order to effect this reform, there will be a new, additional 5\% employer contribution, including the government, implemented over a decade. ${ }^{10}$ This new employer contribution will accrue entirely to a new, collective solidary fund - the so-called "fourth pillar" - that will benefit both current and future pensions. By the same token, workers will keep contributing $10 \%$ of their monthly taxable income to their individual accounts in AFPs. ${ }^{11}$

b) AFPs shall pay back to their clients - the workers-the fees charged in periods of negative profitability for their individual accounts, because "[...] the losses of the workers' pension funds can be a business for no one" (La Tercera Digital, 2016). However, it is unclear if this proposal also applies to the exchange fees, given the impact that it may have on financial investments and managerial practices of the pension industry.

c) Clients will elect representatives who will participate in the administration of AFPs, regarding investment policies, election of directory boards or information campaigns.

c) The government will insist in the congressional passage of the bill that creates a government-owned AFP, which project introduced into Congress almost two years ago. Interestingly enough, this bill project stalled in the House Committee on Labor, because the government withdrew any urgency to discuss it.

d) There will be a review of legislation to suppress social security distortions. Needless to say, this proposal takes aim at the public distribution system that benefits members of the military.

Truthful to a reformist approach, President Bachelet stated that these reforms to the pension system required a dialogue and a national agreement among all actors, though government

\footnotetext{
10 The cost for the government of this new contribution will be about US\$945.000.000 annually (La Tercera Digital, 2016).

11 In a sense, this policy measure was inspired by the Bravo Committee recommendations, but departed from them because it raised monthly contributions from $10 \%$ to $15 \%$ of the workers' monthly taxable income and the new $5 \%$ contribution will go entirely to a collective solidary fund run by the government (the so-called "fourth pillar").
} 
insiders clarified that the backbone of the reform is the creation of a new, collective solidary fund, which seems a non-negotiable measure for the government (La Tercera Digital, 2016).

Despite the presidential initiative, public opinion gave a lukewarm reception to the presidential announcements may be out of weariness with reformist policies, distrust of the government, or something else.

In this respect, reform opponents rapidly solidified their opposition to several of these proposals. They maintained that these reforms will tax middle-class workers, reduce the profitability of pension funds, make more expensive hiring new workers, reduce wages and salaries in the middle-run, subject the pension funds to political pressures, and eliminate workers' freedom to choose the AFP of their choice, besides implying an expropriation (Diario Constitucional, 2016a, 2016b).

Likewise, members of the Bravo Committee, including its chairperson, pointed out early that the new employer contribution may involve a tax on labor, so it may discourage investments and savings in the long-term, unless part of it goes straight into the workers' individual accounts in AFPs (La Tercera Digital, 2016).

Some think tanks even released the results of public opinion polls that tap upon workers' knowledge and perceptions on this reform. These polls suggested that workers rather prefer to have the new employer contribution deposited into their AFPs individual accounts, because they apparently perceive that the latter will increase their future pensions (Diario Constitucional, 2016c; CADEM, 2016). If so, these results would show not only a profound misperception of the pros and cons of the pension system, but also some cultural change among members of the work force.

The political opposition also maintained that the aforementioned contribution constitutes an earmarked tax, which makes it allegedly unconstitutional under Paragraph 3 of Article 19 n. 20 of the Political Constitution (Diario Constitucional, 2016a, 2016b, 2016c). Therefore, any prospective analysis should not discard the possibility that this reform may end up in the docket of the Constitutional Tribunal, which will finally rule on its constitutional validity, like many other reforms, if the political opposition cannot block it in Congress.

Leaders of the social movement, in turn, considered this proposal only as a beginning in the right direction, but withheld specific support for the time being because they want to bring back a public distribution system. Making things worse, the Unitary Central of Workers, the most visible union confederation, plainly rejected to participate in any dialogue that intends to keep AFPs and to support any raise in the retirement age (La Tercera Digital, 2016; Diario Constitucional, 2016a). The latter is criticized from some academic quarters based on the declining natality rates, while a government takeover of all pension funds accrued in AFPs will trigger dislocations in financial markets and probable worsen future pensions (Laderretche, 2016, p. 16), which-by the way- President Bachelet never announced.

Even some senators introduced legislation into Congress to authorize AFPs contributors to withdraw their pension funds to fund specific ventures, like in Peru, which met an outright rejection from the Secretary of Finance (Diario Constitutional, 2016d, 2016e). 
No doubt, the criticisms levelled at the presidential proposals from corporate quarters strongly suggest that this time the stakes are high enough for the pension industry, which justifies the deployment of this sort of across-the-board communicational campaign. After all, it is not far-fetched to conjecture that a success of the fourth pillar may unleash a gradual transformation of the pension system, because it may perfectly displace AFPs as main provider of retirement and disability pensions for most of the population after a couple of decades, after considering the impact of the solidary pillar created eight years ago. In a sense, it is fair to conjecture that the current political conflict on pensions may well be a turning point in the development of Chilean social security and the fulfillment of the fundamental right to social security to all inhabitants of Chile, if properly handled by the Bachelet Administration and the political elite.

\section{Conclusion}

Nowadays Chile is at the crossroads between keeping a predominantly private, market-driven pension system and deepening the mixed features introduced therein eight years ago. The former implies that the government will still fund solidary pensions to the most vulnerable people, while the pension industry siphons off monetary resources from the work force for the benefit of economic actors. The latter implies that employers-including the government-will fund universal solidary pensions for the most vulnerable people, while workers will contribute to their individual accounts in AFPs for the time being.

Although both alternatives keep the contributive component of the pension system in the short-term, only one of them has the potential to evolve over time towards a more distributional system, after considering the impact of aging on population trends in Chile. That is the current presidential proposal which passed by Congress will have a direct impact on people's pensions, even though it is far from being a perfect reform package.

For sure, the presidential proposal does not amount to a public, distribution pension system, but there is not room for such a system in the short-term in Chile, especially after the discrete electoral results obtained by the government coalition as of recently. Nonetheless, it a smart step towards that system under an institutional reform strategy based on layering given the political influence of the pension industry and economic actors who may easily veto the whole reform package in the policy-making process.

It goes without saying that the congressional passage of the presidential proposal will make easier to discuss a transition to a more distributional system in the next ten or fifteen years, once the population trends envisaged by the Bravo Committee become a reality in Chile. Otherwise, Chileans will be discussing again something similar at that time, but under much more detrimental conditions for the general population, as the Bravo Committee surmised it in its final report. Moreover, the breach of the fundamental right to social security will be much greater at that time for the same population. 


\section{References}

Arellano, P. (2012). Universalismo e individualismo en el derecho chileno de pensiones. Santiago: Librotecnia.

Cadem (2016). Plaza Pública. Retrieved from http://www.cadem.cl/wp-content/uploads/2016/08/ Track-PP135-Ago-Sem2-VF.pdf

Diario Constitucional (2016a, Agosto 12). Todo sobre la Reforma Previsional: reacciones a los anuncios de la Presidente. Santiago. Retrieved from http://www.diarioconstitucional.cl/noticias/asuntos-de-interes-publico/2016/08/12/todo-sobre-la-reforma-previsional-reacciones-a-los-anuncios-de-la-presidenta-de-la-republica/

Diario Constitucional (2016b, Agosto 13). Todo sobre la Reforma Provisional: reacciones a los anuncios de la Presidenta de la República. Segunda Parte. Santiago. Retrieved from http://www.diarioconstitucional.cl/noticias/asuntos-de-interes-publico/2016/08/13/todo-sobre-la-reforma-previsional-reacciones-a-los-anuncios-de-la-presidenta-de-la-republica-segunda-parte/

Diario Constitucional (2016c, Agosto 16). Todo sobre la Reforma Provisional: reacciones a los anuncios de la Presidenta de la República. Tercera Parte. Santiago. Retrieved from http://www.diarioconstitucional.cl/noticias/asuntos-de-interes-publico/2016/08/16/todo-sobre-la-reforma-previsional-reacciones-a-los-anuncios-de-la-presidenta-de-la-republica-tercera-parte/

Diario Constitucional (2016d, Agosto 19). Todo sobre la Reforma Provisional: reacciones a los anuncios de la Presidenta de la República. Cuarta Parte. Santiago. Retrieved from http://www.diarioconstitucional.cl/noticias/asuntos-de-interes-publico/2016/08/19/todo-sobre-la-reforma-previsional-reacciones-a-los-anuncios-de-la-presidenta-de-la-republica-cuarta-parte/

Diario Constitucional (2016e, Agosto 20). Todo sobre la Reforma Provisional: reacciones a los anuncios de la Presidenta de la República. Cuarta Parte. Santiago. Retirado de http://www.diarioconstitucional.cl/

Fernández, M. (2012). La Constitución Contra Sí Misma. Precariedad de Derechos y Reforma Constitucional. Santiago: Legal Publishing Thomson Reuters.

Gumucio, A. (2009). Descripción del sistema chileno de seguridad social desde la perspectiva del Convenio Núm. 102 de 1952, OIT. Revista Latinoamericana de Derecho Social, 8, 131-170.

La Tercera Digital (2016, Agosto 9). Presidenta plantea alza a 15\% en cotización para crear pilar de ahorro colectivo solidario. Retrieved from http://www.latercera.com/noticia/politica/2016/08/ 674-692070-9-bachelet-propone-aumentar-gradualmente-cotizaciones-con-cargo-exclusivo-al.shtml

Lanata, G. (2015). Manual de Legislación Previsional. Santiago: Legal Publishing Thomson Reuters.

Landerretche, O. (2016). El regreso al Sistema Previsional de Reparto: una mala idea. Temas de Domingo del 11 al 16 de septiembre de 2016. Talca: Diario El Centro.

Larrañaga, O.; Huepe, M.; Rodríguez, M. (2015). Las Pensiones Solidarias: Análisis de una Reforma Exitosa. In: O. Larrañaga, \& D. Contreras (Eds.), Las Nuevas Políticas Sociales de Protección Social en Chile. Santiago: Uqbar Editores. 
Mahoney, J., \& Thelen, K. (2010). A Theory of Gradual Institutional Change. In J. Maohney, \& K. Thelen (Eds.), Explaining Institutional Change: Ambiguity, Agency, and Power. New York, NY: Cambridge University Press.

Obando Camino, I. (2012). El derecho a la seguridad social en constitucionalismo chileno: un continente en busca de su contenido. Estudios Constitucionales, 10(1), 289-338.

Obando Camino, I. (2016). El régimen jurídico del derecho fundamental a la seguridad social en el Chile: un análisis crítico desde la perspectiva del derecho internacional de la persona humana. Espaço Jurídico Journal of Law, 17(2), 607-648.

O’Donnell, G. (1997). Contrapuntos. Buenos Aires: Paidós.

Pierson, P. (2004) Politics in Time. Princeton: Princeton University Press.

Presidential Advisory Committee on the Pension System (2015). Informe Final. Inhttp://www. comision-pensiones.cl/Documentos/GetInforme

Data da submissão: 09 de dezembro de 2016 Aceito em: 09 de dezembro de 2016 